\title{
Gonadotropin-releasing Hormone Analog
}

National Cancer Institute

\section{Source}

National Cancer Institute. Gonadotropin-releasing Hormone Analog. NCI Thesaurus. Code C1910.

A synthetic analogue of the endogenous hormone gonadotropin-releasing hormone $(\mathrm{GnRH})$, with potential antineoplastic activity. Upon administration, $\mathrm{GnRH}$ analogue mimics endogenous GnRH and strongly binds to and activates pituitary GnRH receptors, which stimulates the synthesis and secretion of the gonadotropic hormones, follicle stimulating hormone (FSH) and luteinizing hormone (LH). Continuous, prolonged activation by the $\mathrm{GnRH}$ analogue results in pituitary $\mathrm{GnRH}$ receptor desensitization and receptor downregulation. This causes inhibition of pituitary gonadotropin secretion of LH and FSH. In males, the inhibition of LH secretion prevents the production and release of testosterone from Leydig cells in the testes and causes a significant decline in testosterone production that is near the levels seen after castration. This may inhibit androgen receptor-positive tumor progression. In females, this results in a decrease in estradiol production. $\mathrm{GnRH}$, also called luteinizing hormone-releasing hormone (LH-RH), is normally synthesized in and secreted by the hypothalamus. Synthetic analogues of GnRH have a stronger receptor binding affinity than the endogenous form. 